\title{
Examination of Vocational Motivations of Physical Education and Sports Teachers in Terms of Some Variances
}

\author{
Levent $\operatorname{Var}^{1} \&$ Mehtap Yildiz ${ }^{2}$ \\ ${ }^{1}$ School of Physical Education and Sports, Kirsehir Ahi Evran University, Kirsehir, Turkey \\ ${ }^{2}$ Faculty of Education, Konya Necmettin Erbakan University, Konya, Turkey \\ Correspondence: Levent Var, Kirsehir Ahi Evran University, School of Physical Education and Sports, Kirsehir, \\ Turkey. E-mail: levent.var@ahievran.edu.tr
}

\author{
Received: December 17, 2018 Accepted: January 10, $2019 \quad$ Online Published: January 17, 2019 \\ doi:10.5539/jel.v8n1p220 \\ URL: https://doi.org/10.5539/jel.v8n1p220
}

\begin{abstract}
The aim of this study is to examine the professional motivations of Physical Education and Sports Teachers. The study group included totally $(\mathrm{n}=300) 93$ female and 207 male physical education and sports teachers working in; Erzurum $(n=30)$, Yozgat $(n=22)$, Kayseri $(n=30)$, Nevsehir $(n=56)$, Aksaray $(n=22)$, Ankara $(n=52)$, Istanbul $(n=44)$ and Kirsehir $(n=40)$ provinces. The research was made in 2017-2018 academic year. As a data collection tool "Vocational Motivation Scale", which consists of 24 items, was developed by Ural (1996). SPSS 22.0 package program was used for statistical analysis of the acquired data and results were evaluated at $\mathrm{p}<0.05$ meaningfulness level. As a result of the research, it was determined that there was a meaningful difference in physical motivation of physical education teachers according to age and seniority, and it was determined that there was a significant difference when their vocational motivations were determined by gender.
\end{abstract}

Keywords: vocational motivation, physical education, sports teacher

\section{Introduction}

Motivation is also very important in the field of physical education and sports as in every profession. It is a factor that directly affects productivity and the motivation source of each occupation group is different (Agirbas et al., 2005).

The concept of motivation is "a process in which direct target activity is started and maintained" (Schunk et al., 2008) or "creating a situation where all the factors that determine the level of desire for the activity are important rather than whether the activity actually exists" (Karaguven, 2012), in other words, it is a total effort to mobilize people in a certain direction and continuity (Karakose \& Kocabas, 2006). Occupational motivation can be defined as the psychological process, which includes all of the behaviors and efforts of the individuals in the workplace where they work in order to fulfill a specific duty or to achieve a tangible spiritual aim (Zeynel \& Carikci, 2015). It is a known reality that individuals with high professional motivation will be more successful in the performance of their profession. When it is considered from this perspective, high motivation in the teaching profession will directly impact the quality of education.

The training process is a set of actions that try to raise qualified people. It is possible to increase the quality of education and increase the qualifications of the educated individuals to reflect their knowledge and skills at the same level as at the mental level as well as at the attitude and behavioral level. The quality of the education received by the students during their education also affects the professional motivation (Herguner et al., 2002). Teachers with high professional motivation educate high quality students. Therefore, it can be said that high professional motivation in teachers' supports quality education and quality education supports vocational motivation.

It is known that physical activity is very important in today's subjects such as the elimination of negativities in the social lives of the individuals, the level of physical proficiency, self-realization and correct expression, and the development of self-confidence. Physical education lessons become outstanding because it is the only area in the curriculum that supports physical and mental improvement at the same time (Wuest \& Bucher, 1999). These days, there are studies about impression of physical education on academic success in a positive way (Silliker \& Quirk, 1997; Whitley, 1999; Linder, 1999; Langbein \& Bess, 2002; Garber, 1996; Er, 2010). 
The achievement of the objectives of physical education courses, high standards and high quality of teachers are directly related to the professional motivation of teachers (Herguner et al., 2002; Agirbas et al., 2005; Ada et al., 2013). Motivation sources and the place where teachers position their vocations in their profession are among the factors that directly affect communication and interaction with students (Erjem, 2005). Considering the direct relationship between the level of professional motivation and the quality of education (Herguner et al., 2002), determining the factors motivating the physical education teachers and decreasing their motivation by means of determining the situation, increasing the motivation resources, eliminating the negativities and thus the professional productivity of the teachers is determined and all of these studies are gaining importance. In this study, it is aimed to examine the motivation of physical education and sports teachers in terms of some variances.

\section{Method}

This part presents information about the model of the research, the study group, collection of data and information about its analysis.

\subsection{Research Model}

This research is a descriptive study which is patterned in relational survey model. The survey model aims to present a situation that is existed in the past or in current time (Karasar, 2015). In this study, it is aimed to examine the motivation of physical education and sports teachers in terms of some variables.

\subsection{Study Group}

The study group consisted of totally ( $\mathrm{n}=300) 93$ female and 207 male physical education and sports teachers working in Erzurum $(n=30)$, Yozgat $(n=22)$, Kayseri $(n=30)$, Nevsehir $(n=56)$, Aksaray $(n=22)$, Ankara $(n=52)$, Istanbul $(\mathrm{n}=44)$ and Kirsehir $(\mathrm{n}=40)$ provinces. The research was made in 2017-2018 academic year.

\subsection{Collecting of Data}

For the measurement of the professional motivations of physical education and sports teachers who participated in the study, a professional motivation scale was used which was developed and used by Ural and used in various studies (Ural, 2007; Sener, 2009). In the first study that the psychometric limitations done while scale was consisting of 28 items, with other studies of the researcher the item number decreased to 24 and it is evaluated with a Likert type scale (I have never felt, I sometimes feel, I frequently feel, I always feel). The validity and reliability tests of the scale were found valid and reliable. The Cronbach alpha coefficient of the scale is determined as 0.91 . Validity studies were conducted using expert evaluation and factor analysis. As a result of the factor analysis, the sub-dimensions were determined. 5 factors were determined as a result of the factor analysis on the Professional Motivation Scale. These factors are: Love the Job, Duty Love, Economic Insufficiency of the Profession, Restriction of the Profession, Economic Benefits of the Profession. In this study, the reliability of the scale for this research group was re-checked and the reliability coefficient was found as 0.84 in the Cronbach Alpha internal consistency test. One of the researches used in the study was "The Project of Passing from Preschool to Primary Schools" in 2007 with Marmara University, UNICEF and the Ministry of National Education.

\subsection{Statistical Analysis}

SPSS 22.0 package program was applied for statistical analysis of the obtained data and results were evaluated at $\mathrm{p}<0.05$ meaningfulness level. The normality test was applied to determine if the data show adaptability with normal distribution. Kolmogorov-Smirnov table was examined because the number of subjects in the educational level was above 30 (300) (Alpar, 1997). According to Kolmogorov-Smirnov; since variables are ( $>>0.05$ ) level they were distributed normally. Therefore, parametric test was applied to the variables. Demographic characteristics and vocational motivation score of the subjects according to provinces (Table 1) and frequency and percentage analysis for the distribution analysis of the responses given to the vocational motivation survey of the participants in the study (Table 2), Independent-Samples T Test (Table 3), according to age (Table 4) and seniority (Table 5), One-Way ANOVA analysis was conducted to compare the professional motivation scores of the subjects.

\section{Results}

This part includes information about the acquired findings of the research. 
Table 1. Demographical characteristics and vocational motivation points of subjects according to provinces

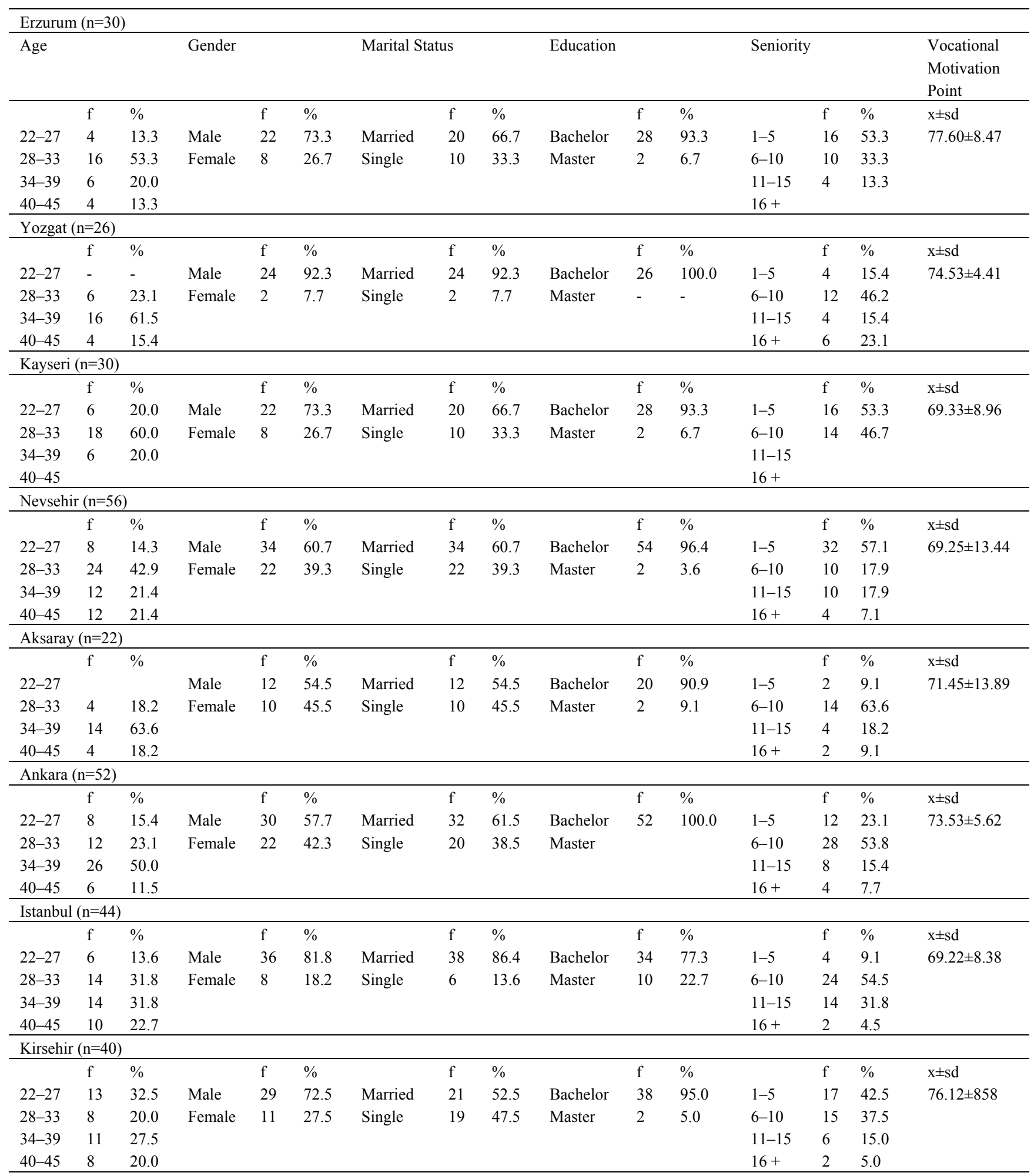

When Table 1 is examined, demographic distribution and occupational motivation scores of the study group are observed. The study group consisted of women $n=93$, male $n=207$ totally $n=300$ people. According to the distribution of the group by province, Erzurum $n=30$, Yozgat $n=22$, Kayseri $n=30$, Nevsehir $n=56$, Aksaray $n=22$, Ankara $n=52$, Istanbul $n=44$, Kirsehir $n=40$ people. The province with the highest professional motivation score is Erzurum with 77.60 points and the province with the lowest professional motivation score is Istanbul with a score of 69.22 . These findings point out that the highest level of professional motivation of physical education 
teachers working in Erzurum province and the lowest motivation of physical education and sports teachers working in Istanbul. Moreover, it is seen that teachers' general vocational motivation points are seen as high.

Table 2. Frequency and percentage distribution of the subjects' answers given for the vocational motivation survey

\begin{tabular}{|c|c|c|c|c|c|c|c|c|c|}
\hline & \multirow{2}{*}{$\begin{array}{l}\text { Vocational Motivation } \\
(\text { Cronbach's Alpha }=0.84)\end{array}$} & \multicolumn{2}{|l|}{ Never } & \multicolumn{2}{|c|}{ Sometimes } & \multicolumn{2}{|c|}{ Frequently } & \multicolumn{2}{|c|}{ Always } \\
\hline & & $\mathrm{f}$ & $\%$ & $\mathrm{f}$ & $\%$ & $f$ & $\%$ & $\mathrm{f}$ & $\%$ \\
\hline 1 & I love my job. & 19 & 6.3 & 8 & 2.7 & 14 & 4.7 & 259 & 86.3 \\
\hline 2 & $\begin{array}{l}\text { I like thinking that I'm doing my job/mission in a right } \\
\text { way. }\end{array}$ & 4 & 1.3 & 8 & 2.7 & 68 & 22.7 & 220 & 73.3 \\
\hline 3 & $\begin{array}{l}\text { Promoting in my profession, promotion opportunities } \\
\text { are limited. }\end{array}$ & 32 & 10.7 & 109 & 36.3 & 97 & 32.3 & 62 & 20.7 \\
\hline 4 & I do my job to continue my life in a specific order. & 26 & 8.7 & 78 & 26.0 & 78 & 26.0 & 118 & 39.3 \\
\hline 5 & $\begin{array}{l}\text { The job areas/workplaces are very limited that I will } \\
\text { work for. }\end{array}$ & 30 & 10.0 & 153 & 51.0 & 81 & 27.0 & 36 & 12.0 \\
\hline 6 & I think my job is among the respectable professions. & 20 & 6.7 & 32 & 10.7 & 53 & 17.7 & 195 & 65.0 \\
\hline 7 & $\begin{array}{l}\text { I didn't choose this profession willingly, but now I love } \\
\text { it. }\end{array}$ & 148 & 49.3 & 47 & 15.7 & 38 & 12.7 & 67 & 22.3 \\
\hline 8 & I think I serve humanity thanks to my profession. & 14 & 4.7 & 24 & 8.0 & 85 & 28.3 & 177 & 59.0 \\
\hline 9 & I don't want to, but I need to do this job. & 106 & 35.3 & 67 & 22.3 & 65 & 21.7 & 62 & 20.7 \\
\hline 10 & Whether I want or not conditions make to do this job. & 14 & 4.7 & 20 & 6.7 & 61 & 20.3 & 203 & 67.7 \\
\hline 11 & $\begin{array}{l}\text { Being among the ones who carry on this profession } \\
\text { makes me feel happy }\end{array}$ & 188 & 62.7 & 74 & 24.7 & 10 & 3.3 & 28 & 9.3 \\
\hline 12 & I wish I had studied in another area and had another job. & 14 & 4.7 & 16 & 5.3 & 42 & 14.0 & 228 & 76.0 \\
\hline 13 & $\begin{array}{l}\text { It makes me happy to think that I am successful in doing } \\
\text { my job. }\end{array}$ & 2 & .7 & 20 & 6.7 & 52 & 17.3 & 226 & 75.3 \\
\hline 14 & I think my profession is invaluable. & 8 & 2.7 & 48 & 16.0 & 78 & 26.0 & 166 & 55.3 \\
\hline 15 & $\begin{array}{l}\text { It makes me feel relax by knowing that I will earn } \\
\text { money every month. }\end{array}$ & 14 & 4.7 & 38 & 12.7 & 44 & 14.7 & 204 & 68.0 \\
\hline 16 & $\begin{array}{l}\text { Since I have such a profession, I look to the future with } \\
\text { confidence. }\end{array}$ & 20 & 6.7 & 62 & 20.7 & 60 & 20.0 & 158 & 52.7 \\
\hline 17 & $\begin{array}{l}\text { When I retire, it makes me comfortable to think that I } \\
\text { will have a retirement salary guarantee. }\end{array}$ & 129 & 43.0 & 117 & 39.0 & 24 & 8.0 & 30 & 10.0 \\
\hline 18 & I was disappointed while I was doing my job. & 16 & 5.3 & 28 & 9.3 & 67 & 22.3 & 189 & 63.0 \\
\hline 19 & The best job I can do is to do my job. & 126 & 42.0 & 110 & 36.7 & 26 & 8.7 & 38 & 12.7 \\
\hline 20 & $\begin{array}{l}\text { I can give up my profession and do a job in another } \\
\text { field. }\end{array}$ & 10 & 3.3 & 20 & 6.7 & 30 & 10.0 & 240 & 80.0 \\
\hline 21 & It's a treasure to have a job. & 6 & 2.0 & 16 & 5.3 & 49 & 16.3 & 229 & 76.3 \\
\hline 22 & $\begin{array}{l}\text { It makes me happy to know that I'm fulfilling things in } \\
\text { life while I am doing it. }\end{array}$ & 176 & 58.7 & 80 & 26.7 & 12 & 4.0 & 32 & 10.7 \\
\hline 23 & I do not do this job if I don't need money. & 10 & 3.3 & 21 & 7.0 & 47 & 15.7 & 222 & 74.0 \\
\hline \multirow[t]{2}{*}{24} & $\begin{array}{l}\text { While I am doing this job, being respected by the } \\
\text { environment makes me happy. }\end{array}$ & 8 & 2.7 & 16 & 5.3 & 62 & 20.7 & 214 & 71.3 \\
\hline & Average & 47.50 & 15.84 & 50.50 & 16.84 & 51.79 & 17.27 & 150.13 & 50.04 \\
\hline
\end{tabular}

When Table 2 is examined, frequency and percentage distributions of the answers given to the questions of professional motivation scale are seen. These findings show that physical education and sports teachers love their profession very much $(91.0 \%)$ and see them as very valuable $(92.6 \%)$, that they fulfill their job requirements (96.0\%) and think of themselves as successful in their profession (90\%).

Physical education and sports teachers love the professions, think that their profession is fulfilling the requirements/duties of the profession, think that the teaching profession is among the respectable professions, they serve humanity through their professions, being happy to be among the teachers of physical education, being a physical education teacher of their professions, to be successful in their profession to think that they are invaluable and their professions are invaluable, to know that they will earn salaries every month regularly, to look at the future with confidence because they have such professions, to think that they will have salary guarantees when they retire, not to be very disappointed in doing professions, to think of their profession as the best job they can do, little to think about doing something else that they think that having a profession is a gold 
bracelet, knowing that they have a duty in life while doing their profession, thinking that they do not have to do their jobs because they need money, they think their profession is a very enjoyable job, respecting their environment, high education of physical education and sports teachers and after all it can be said that it is the reason of their motivation.

Physical education and sports teachers, the step up in career and promotion opportunities, they think they can work related to their vocation is very limited in the areas of their branch and decrease their vocational motivation, in order to maintain their profession in a certain order, whether they want to do this profession or not, even if they have chosen this job unwillingly but now they love doing this job now, it can be said that there is not a positive or negative effect on their professional motivation level.

Table 3. Comparison of subjects' vocational motivation points depending on genders

\begin{tabular}{lcccc}
\hline Gender & $\mathrm{n}$ & $\mathrm{x} \pm \mathrm{sd}$ & $\mathrm{t}$ & $\mathrm{p}$ \\
\hline Male & 207 & $73.42 \pm 9.11$ & 2.756 & $.006^{* *}$ \\
Female & 93 & $70.04 \pm 11.07$ & & \\
\hline
\end{tabular}

Note. ${ }^{* *} \mathrm{p}<0.01$.

It is observed that there is a meaningful difference in the physical motivation of physical education teachers according to gender. Males have a higher score than females.

Table 4. Comparison of subjects' vocational motivation points depending on ages

Note. $\mathrm{p}>0.05$.

\begin{tabular}{llll}
\hline Age & Age & $\mathrm{x} \pm \mathrm{sd}$ & $\mathrm{p}$ \\
\hline $22-27$ & $28-33$ & $1.08 \pm 1.77$ & .928 \\
& $34-39$ & $1.32 \pm 1.76$ & .876 \\
& $40-45$ & $1.50 \pm 2.05$ & .883 \\
$28-33$ & $22-27$ & $-1.0 \pm 1.77$ & .928 \\
& $34-39$ & $.23 \pm 1.38$ & .998 \\
& $40-45$ & $.42 \pm 1.73$ & .995 \\
$34-39$ & $22-27$ & $-1.32 \pm 1.76$ & .876 \\
& $28-33$ & $-.23 \pm 1.38$ & .998 \\
& $40-45$ & $.18 \pm 1.72$ & 1.000 \\
$40-45$ & $22-27$ & $-1.50 \pm 2.05$ & .883 \\
& $28-33$ & $-.42 \pm 1.73$ & .995 \\
& $34-39$ & $-.18 \pm 1.72$ & 1.000 \\
\hline
\end{tabular}

There is not a meaningful difference in the physical motivation of physical education teachers according to age. Age does not have an impact on vocational motivation.

Table 5. Comparison of subjects' vocational motivation points depending on their seniorities

Note. $\mathrm{p}>0.05$

\begin{tabular}{llll}
\hline Seniority & Seniority & $\mathrm{x} \pm \mathrm{sd}$ & $\mathrm{p}$ \\
\hline $1-5$ & $6-10$ & $2.39 \pm 1.31$ & .262 \\
& $11-15$ & $-.23 \pm 1.70$ & .999 \\
& 16 and over & $-.13 \pm 2.40$ & 1.000 \\
$6-10$ & $1-5$ & $-2.39 \pm 1.31$ & .262 \\
& $11-15$ & $-2.63 \pm 1.64$ & .379 \\
& 16 and over & $-2.53 \pm 2.36$ & .708 \\
$11-15$ & $1-5$ & $.23 \pm 1.70$ & .999 \\
& $6-10$ & $2.6 \pm 1.64$ & .379 \\
& 16 and over & $.10 \pm 2.60$ & 1.000 \\
16 and over & $1-5$ & $.13 \pm 2.40$ & 1.000 \\
& $6-10$ & $2.53 \pm 2.36$ & .708 \\
& $11-15$ & $-.10 \pm 2.60$ & 1.000 \\
\hline
\end{tabular}


When the professional motivations of the physical education teachers are considered according to their seniority, there is not a meaningful difference found. Seniority does not affect vocational motivation.

\section{Discussion}

When the results of the study and literature are examined, it is observed that the level of vocational motivation varies according to many variables. It is thought that more comprehensive and numerous studies should be done in order to understand the factors well that both positively and negatively affect motivation

When the motivation in terms of gender differences is examined, Alemdag et al. (2014) reached out the result that the level of academic motivation of physical education and sports teacher candidates is higher in females (Alemdag et. al., 2014). In studies of Sahin and Cakar (2011) for bachelor students and in studies of Demir and Ari (2013) on teacher candidates in the elementary school have reached the conclusion that the level of academic motivation has not changed significantly by gender (Sahin \& Cakar, 2011; Demir \& Ari, 2013). In studies of Saracaloglu (2008) in master students and in studies of Saracaloglu and Kumral (2007) and Saracaloglu et al. (2008a, 2008b) similar results were obtained from teacher candidates (Saracaloglu \& Kumral, 2007; Saracaloglu et al., 2008a; Saracaloglu et al., 2008b). In the study where Eymur and Geban (2011) examined teachers candidates' academic motivation and academic achievement, only one of the seven motivational subscales (inner motivation/experiencing stimulation) found that the motivation scores of the girls were meaningfully higher than the males (Eymur \& Geban, 2011). Alike, in studies about examining the motivations of physical education teacher candidates, Gencay and Gencay (2007) found that female teacher candidates' motivation scores were high (Gencay \& Gencay, 2007), but Tekin et al. (2009) found that male teacher candidates' have higher motivation levels (Tekin et al., 2009). In the study, the motivation levels of males were found to be higher than females in the same way as in the study of Tekin et al. (2009). This result indicates difference when compared to the general view of the literature. It is thought that this difference may be derived from such as the socio-cultural structure of the regions where the study is performed, the physical conditions of the schools where the teachers work and the management structures.

The success of educational institutions depends on the capacities of people in the institution, their willingness, their ability to work and their ability levels (Agirbas et al., 2005). Maslow stated that when individuals joined to an organization they have brought the some specific requirements together such as; psychological, physiological and social values (Ozturk \& Dundar, 2003). The level of fulfillment of these necessities may affect the motivation status. Le Compte and Dworkin (1991) stated that teachers' successful performance of the teaching role depends on many factors such as the structure of the institution they work, managerial processes, student profile education programs, socioeconomic opportunities, and the lack of teachers in the desired position in terms of these factors. They also expressed their idea that their lives were keeping them away from the job (Le Compte \& Dworkin, 1991). Knoop (1982), determined that especially the difficulties faced in teaching, the stress caused by the professional circumstances, the lack of communication among teachers, external control, excessive workload, the existence of high-class population negatively affect the job satisfaction and therefore it has caused to a lack of motivation (Knoop, 1982).

In a study of Ada et al. (2013) about motivation factors of teachers their (Erzurum province example) they determined that parents' and students' interest towards teachers, principals' approvals for the studies of teachers, appreciation, trustworthy and supportive attitudes, the educational service offered by the teachers, parents stated that the development of the students that the teacher realize, the existence of sufficient tools and equipment in the classroom are one of the specific motivating external factors for teachers (Ada et al., 2013).

In this study, the different distribution of the high motivation scores among the provinces, the living conditions of the teachers involved, the financial benefits, time management, physical conditions in the institution, student profile, value given to the teacher, relationship between human relations, administration-teacher, feedback from the students. So it can be said that the psychological, physiological and sociological needs such as reflection of parent satisfaction, workload distribution, social activity level and differences in the level of meeting these requirements are covered. The results of the study show similarity with the literature.

Ceyhan (2004), mentioned in the study; loving a job, being one of the most crucial determinants of the work done to be satisfied with the work they do, does not mean that they are satisfied with the work they do, does not mean that they are happy with the work and the profession of the work that is not happy, individuals who are not fully satisfied with their expectations, it is possible to give examples from many professions (Ceyhan, 2004). In the light of the results obtained from the study, $91 \%$ of 300 physical education and sports teachers (Table 2) stated that they liked their profession, but it is thought that the increase in their professions and the limited opportunities for promotion consider their occupational motivations to think that their job fields are very limited. 
From another perspective, it is seen that the fact that they are doing this profession in order to be able to maintain their lives in a certain order, whether they want to do this profession and whether they do not choose this profession but they do not have any impact on their vocational motivations.

Agirbas et al. (2005) stated in their study that motivation is a process that focuses on meeting various needs (Agirbas et al., 2005). Alemdag et al. (2014) suggested in their study about academic motivation and academic self-sufficiency of physical education teacher candidates and with the study results of Sahin and Cakar (2011) about the effect of academic strategies on learning strategies and academic motivation levels of faculty students revealed that motivation levels of teacher candidates were over the normal levels (Alemdag et al., 2014; Sahin \& Cakar, 2011). It can be expressed that highness of the motivation levels of physical education teachers thanks to their jobs both their materialistic and spiritual needs and expectations of environment also covered.

This high level of motivation faced in physical education teachers is different from most professions in the occupational selection stage in the form of orientation (taking special ability examination etc.), and many of the individuals who prefer this vocation in their previous experiences are professional and amateur activities. It is thought that sporting activities can be continued within the aspect of lifelong sport stage. Besides, students' interest in physical education courses, these courses have an aspect that appeals to each student in addition to sportive gains as well as the social gains of the students through the bond between the students and the students (compliance with the rules, movement with the group, civilized behavior, fair-play, taking responsibility, discipline) it is thought that the motivation of teachers is high due to the fact that factors such as discipline, communication skills and supporting self-confidence enhancement keep teachers' vocational satisfaction at the high level.

\section{References}

Ada, S., Akan, D., Ayik, A., Yildirim, I., \& Yalcin, S. (2013). Motivation factors of teachers. Ataturk University Journal of Social Sciences Institute, 17(3), 151-166. Retrieved from http://dergipark.gov.tr/download/articlefile/32419

Agirbas, I., Celik, Y., \& Buyukkayikci, H. (2005). Motivation means and job satisfaction: a study on deptuy of head physicians working at the hospitals of department of social insurance organization. Hacettepe Journal of Health Administration, 8(3), 326-350. Retrieved from http://dergipark.gov.tr/download/article-file/84671

Alemdag, C., Oncu, E., \& Yilmaz, A. K. (2014). Preservice Physical Education Teachers' Academic Motivation and Academic Self-Efficacy. Hacettepe Journal of Sport Sciences, 25(1), 23-35. Retrieved from http://dergipark.gov.tr/sbd/issue/16369/171304

Alpar, R. (1997). Uygulamali Cok Degiskenli Istatistiksel Yontemlere Giris-I. Ankara: Bagirgan Yayimevi.

Ceyhan, R. (2004). Evaluation of shift work practices in Ministry of Health Hospitals. Hacettepe University Institute of Health Sciences, Science Specialist Thesis, Ankara.

Demir, M. K., \& Ari, E. (2013). Examining the academic motivation levels of teacher candidates in terms of various variables. Theory and Practice in Education, 9(3), 265-279. Retrieved from http://dergipark.gov.tr/download/article-file/63346

Er, F. (2010). Comparison of relationship between physical fitness levels and academic success of university students regularly and not regularly sporting. Master Thesis, Gazi University Faculty of Education Sciences, Ankara.

Erjem, Y. (2005). A phenomenon of alienation in education and teacher: a sociological research on high school teachers. Turkish Journal of Educational Sciences, 3(4), 395-417. Retrieved from http://dergipark.gov.tr/tebd/issue/26122/275175

Eymur, G., \& Geban, O. (2011). Examining the relationship between motivation and academic achievement of chemistry teacher candidates. Education and Science, 36(161), 246-255. Retrieved from http://egitimvebilim.ted.org.tr/index.php/EB/article/view/987/299

Garber, S. B. (1996). Extra curricular activities and academic achievement. Journal of Reseach and Development in Education, 30(1), 42-50. Retrieved from http://psycnet.apa.org/record/1997-02671-005

Gencay, O. A., \& Gencay, S. (2007). Examining the motivation levels of the students of physical education and sports high school in terms of some variables. Selcuk University Journal of Social Sciences Institute, 17(2), 241-253. 
Herguner, G., Arslan, O. G. S., \& Dundar, A. G. H. (2002). Level of perception of school experience of students in physical education and sports teaching department. Pamukkale University Faculty of Education Journal, 11(11), 44-58. Retrieved from http://dergipark.gov.tr/download/article-file/114846

Karaguven, M. H. (2012). Adaptation of academic motivation scale to Turkish. Educational Sciences Theory and Practice, 12(4), 2599-2620. Retrieved from http://www.estp.com.tr/tr/tum-sayilar/12

Karakose, T., \& Kocabas, I. (2006). The effect of teachers' expectations on job satisfaction and motivation in private and public schools. Journal of Theory and Practice in Education, 2(1), 3-14. Retrieved from http://dergipark.gov.tr/download/article-file/63250

Karasar, N. (2015). Scientific Method. Ankara: Nobel Publisher.

Knoop, R. (1982). Alienated teacher: a. profile. Teaching and Teacher Education, 4(3), 21-28. Retrieved from http:// www.ebsco.com

Langbein, L., \& Bess, R. (2002). Sport in school: scource of amit your antipathy? Social Science Quarterly, 83(2). https://doi.org/10.1111/1540-6237.00093

Le Compte, M. D., \& Dworkin, A. G. (1991). Giving up on School: Student Drapouts and Teacher Burnouts. Carwin Press Inc.

Linder, K. J. (1999). Sport participation and perceived academic performance of school children and youth. Pediatric Exercise Science, 11(1), 129-143. https://doi.org/10.1123/pes.11.2.129

Ozturk, Z., \& Dundar, H. (2003). Organizational Motivation and Factors Motivating Public Employees. C.U. Journal of Economics and Administrative Sciences, 4(2), 57-67. Retrieved from https://s3.amazonaws.com/academia.edu.documents/32136296

Sahin, H., \& Cakar, E. (2011). The effect of learning strategies and academic motivation levels of academic faculty students on academic achievement. Turkish Journal of Educational Sciences, 9(3), 519-540. Retrieved from http://dergipark.gov.tr/tebd/issue/26099/274993

Saracaloglu, A. S., Karasakaloglu, N., \& Yenice, N. (2008a). The relationship between academic motivation level of primary school teachers, their views on science and social sciences and their academic achievement. VII. National Classroom Education Education Symposium, Canakkale Onsekiz Mart University.

Saracaloglu, A. S., Kumral, O., \& Kanmaz, A. (2008b). The qualifications, concerns and levels of academic motivation of the Bachelor students who are the teachers of higher education without social sciences. International Social Sciences Education Symposium, Canakkale Onsekiz Mart University.

Saracaloglu, A. S., \& Kumral, O. (2007). Examination of the proficiency perceptions, concerns and academic motivation levels of the primary school students in terms of various variables. VI. National Classroom Teaching Education Symposium, Eskişehir Anadolu University.

Saracaloglu, A. S. (2008). The relationship between academic motivation levels, research concerns and attitudes and research competencies of master students. Yuzuncu Yil University Faculty of Education Journal, 5(2), 179-208. Retrieved from http://dergipark.gov.tr/download/article-file/146339

Schunk, D. H., Pintrich, P. R., \& Meece, J. L. (2008). Motivation in education: Theory, research, and applications (2nd ed.). New Jersey: Prentice Hall.

Sener, M. M. (2009). The Effect of In-Service Training on the Class Teachers' Motivation Levels. Marmara University Institute of Educational Sciences, Master Thesis, Istanbul.

Silliker, S. A., \& Quirk, J. T. (1997). The effect of extracurricular activity participation on the academic performance of male and female high school students. The School Counsulor, 44(4), 288-293. Retrieved from https://www.jstor.org/stable/23897929

Tekin, M., Tasgin, O., Yildiz, M., \& Lok, S. (2009). The level of motivation of the teacher candidates studying in the physical education and sports college. 6. National Physical Education and Sports Teaching Symposium, Burdur Mehmet Akif University.

Ural, O. (2007). Problems in Master Education. III. Master Education Symposium, Eskisehir: Anadolu University. 
Whitley, R. L. (1999). Those Dumb Jacks are it again: A comparison of the Educational performances of athletes and nonathletes in North Carolina high Schools from 1993 through 1996. High School Journal, 82(4), 1-9. Retrieved from https://www.researchgate.net/journal/1534-5157_The_High_School_Journal

Wuest, D. A., \& Bucher, C. A. (1999). Foundations of Physical Education and Sport (pp. 43-45). Boston: McGraw-Hill.

Zeynel, E., \& Carikci, I. H. (2015). The effect of professional motivation on job satisfaction and organizational commitment: an empirical study on academicians. Suleyman Demirel University Journal of Faculty of Economics \& Administrative Sciences, 20(3), 217-248. Retrieved from http://iibfdergi.sdu.edu.tr/assets/uploads/sites/352/files/yil-2015-cilt-20-sayi-3-yazi-12-11092015.pdf

\section{Copyrights}

Copyright for this article is retained by the author, with first publication rights granted to the journal.

This is an open-access article distributed under the terms and conditions of the Creative Commons Attribution license (http://creativecommons.org/licenses/by/4.0/). 